\title{
Climate change vulnerability assessment of the coastal resources in Moalboal, Cebu, Central Philippines
}

\author{
Annie G. Diola, 3*, Wenifel P. Perpetcho', Juan Carlos A. Graciosa ${ }^{1,2}$, \\ Glacy Dee B. Pantanosas', Rhys H. Montecillo, , Shena Mae M. Flores', \\ Renante R. Violanda' ${ }^{1,2}$, Roland Emerito S. Otadoy ${ }^{1,2}$ and Danilo T. Dy ${ }^{1,3}$
}

The municipality of Moalboal (Cebu, Central Philippines) falls under Cluster $\mathrm{XI}$ (coastal and marine areas of the south Sulu Sea are most prone to sea level rise) in the climate-ocean hazard typology. Coastal activities, such as aquaculture, fishing, recreation, and tourism are integral to Moalboal's economy. Its economy is partly dependent on coastal resources and could be vulnerable to sea level rise. Hence, there is a need to determine the vulnerability profile of the municipality, through indicator-based vulnerability assessment. Results using vulnerability assessment tools coupled with GIS-based workflows showed that the overall vulnerability to climate change of mangroves was moderate and low for both seagrasses and corals. A better understanding of how human activities may directly and indirectly affect coastal resources is urgently needed. Integrated coastal zone management provides a major opportunity to address the many issues and challenges of climate change in an effort to design and develop adaptation strategies.

Keywords: climate change, climate risk, climate adaptation, GIS, Moalboal

\section{INTRODUCTION}

The Philippine archipelago of 7,100 islands has a coastline of $34,000 \mathrm{~km}$ and its coastal resources are expected to be at risk from climate change. Predicted effects of climate change, such as rising sea level, changes in oceanic circulation, rainfall patterns, frequency and intensity of storms are highly likely to affect coastal habitats (eg, mangroves, seagrasses and corals). Global climate models project

'Phil-LiDAR Research Center, University of San Carlos, Cebu City 6000, Cebu, Philippines

${ }^{2}$ Theoretical and Computational Sciences and Engineering Group, Department of Physics, University of San Carlos, Cebu City 6000, Cebu, Philippines

${ }^{3}$ Department of Biology, University of San Carlos, Cebu City 6000, Cebu, Philippines *Corresponding Author. Address: Department of Biology, University of San Carlos, Cebu City 6000, Cebu,
Philippines; Email:agdiola@usc.edu.ph 
the possibility that typhoons and storms will become more intense within the Western Pacific typhoon belt (between the Tropic of Cancer and the Equator, $5^{\circ} \mathrm{N}$ and $60^{\circ} \mathrm{N}$ latitude) over the remainder of this century (Bloemendaal et al 2020). The adverse effects of climate change on tropical coastal habitats and aquaculture resources are likely to be devastating even in coastal areas which are geomorphologically sheltered by neighboring islands, water channels or insular shelves. The vulnerability of the Philippine islands is expected to increase as a result of climate change. Multiple stressors interact to affect the coastal resources and the people who depend on them (Nicholls et al 2007, Rosenzweig et al 2007, Perez 2011). An increase in the intensity of climatic extremes such as storms, coupled with other impacts of climate change and the effects of human development along the coasts, could affect the sustainability of many existing coastal communities and natural resources. Coastal communities will need strategies to enable them to manage current stressors and the confounding impacts of a changing climate to conserve, protect and restore coastal habitats.

Climate change vulnerability is a function of climate exposure, sensitivity and adaptive capacity (Intergovernmental Panel on Climate Change 1996). The IPCC introduced the concept of climate change vulnerability in the framework of CCIVA (Climate Change Impact and Vulnerability Assessment) which combines both biophysical and socio-economic aspects (IPCC 1996). Assessing a coastal area's vulnerability to the impacts of climate change involves understanding: (1) the possible magnitude of climate change for a given region or locality; (2) what is at risk (climate change exposure and sensitivity); and (3) the capacity of society to cope with the expected or actual climate changes (adaptive capacity) (MERF 2013). Combining these three factors defines the vulnerability of the coastal communities to climate change. Coastal adaptation to climate change is especially important because of the increasing population living in coastal regions around the world and the existing problems due to high exploitation of coastal resources may be aggravated by climate change risk (United Nations Environment Programme 2002, Wong et al 2014). The assessment of vulnerability to climate change is essential to create relevant adaptation policies (Yoo et al 2011). This study was conducted to assess the vulnerability to climate change of a coastal community in Moalboal, Cebu, Philippines.

\section{MATERIALS AND METHODS}

\section{Study Area}

Moalboal is a $4^{\text {th }}$ municipal income class municipality in the province of Cebu. It is one of the 44 coastal municipalities of the province of Cebu with a total population of 27,676 with $73 \%$ of the population living in coastal villages or barangays (Philippine Statistics Authority 2010). It is located at the southwestern portion of Cebu Island. It has a total land area of $7,290.95$ ha with a $26.6 \mathrm{~km}$ coastline. The municipality is composed of 15 barangays; 8 of which are considered coastal barangays namely: Saavedra, Tuble, Basdiot, Poblacion East, Poblacion West, Tomonoy, Balabagon, and Tunga. 
Traditionally, Moalboal has been recognized as one of the popular tourist destinations in the country. SCUBA diving and snorkeling are the major tourism activities mainly in barangays Saavedra, Tuble and Basdiot. Aside from fishing, these tourism activities are considered major sources of revenue or income for the Local Government Units (LGUs) and the people living in the coastal barangays.

\section{Vulnerability Assessment Components, Criteria and Assessment Framework}

The vulnerability of a system to climate change is measured by evaluating the relevant factors associated with each of the three components (exposure, sensitivity, and adaptive capacity) (Figure 1). Integration of these three components yields a measure of vulnerability. The Integrated Coastal Sensitivity, Exposure, and Adaptive Capacity to Climate Change VA Tool or I-C-SEA Change and the Coastal Integrity VA Tool or CIVAT were used in this study (MERF 2013). I-C-SEA Change considers sea level rise, waves and storm surges, sea surface temperature, and rainfall as exposure factors vis-à-vis fisheries and coastal integrity functions of the coastal and marine ecosystem. CIVAT measures the vulnerability of the physical coast by analyzing natural and anthropogenic factors driving beach processes. The assessment framework in this study is adapted from MERF (2013).

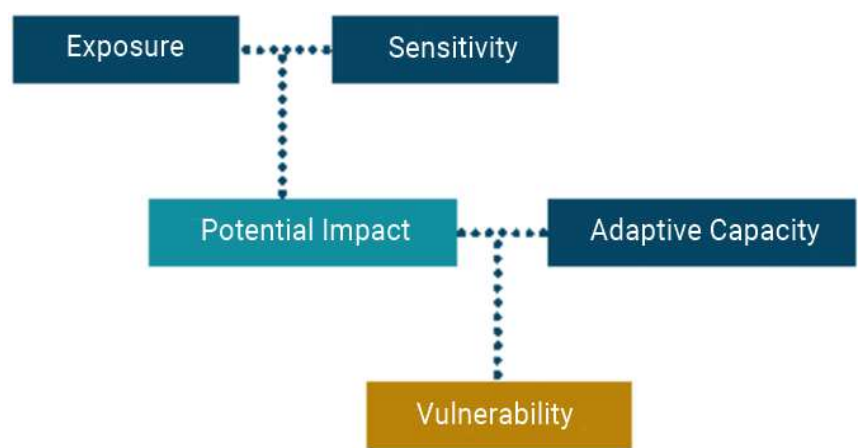

Figure 1. Vulnerability as a function of Exposure, Sensitivity, and Adaptive Capacity (MERF 2013)

\section{Pre-Vulnerability Assessment}

The spatial unit of assessment was the 8 coastal barangays of the municipality of Moalboal. Prior to the actual survey, a site visit was conducted to the LGUs (municipal and barangay) and civil society groups or people's organizations. Relevant secondary data (ie, comprehensive land use map, environmental ordinances) was also gathered during the initial visit to avoid redundancy.

\section{Vulnerability Assessment: Characterizing Exposure}

Scoring for exposure was based on a typology of climate-related coastal parameters in the Philippines as suggested by David et al (2015). The municipality of Moalboal falls under Cluster XI (coastal and marine areas of the south Sulu Sea has the relative exposure typology of sea level rise). In order to describe the present 
state of the coastal ecosystem of Moalboal that responds to the exposure factor (ie, sea level rise) arising from changes in climate, a rapid resource assessment (RRA) was done per coastal barangay and establishment of sampling sites were based on the initial RRA survey data (Figure 2).

Municipality of Moalboal

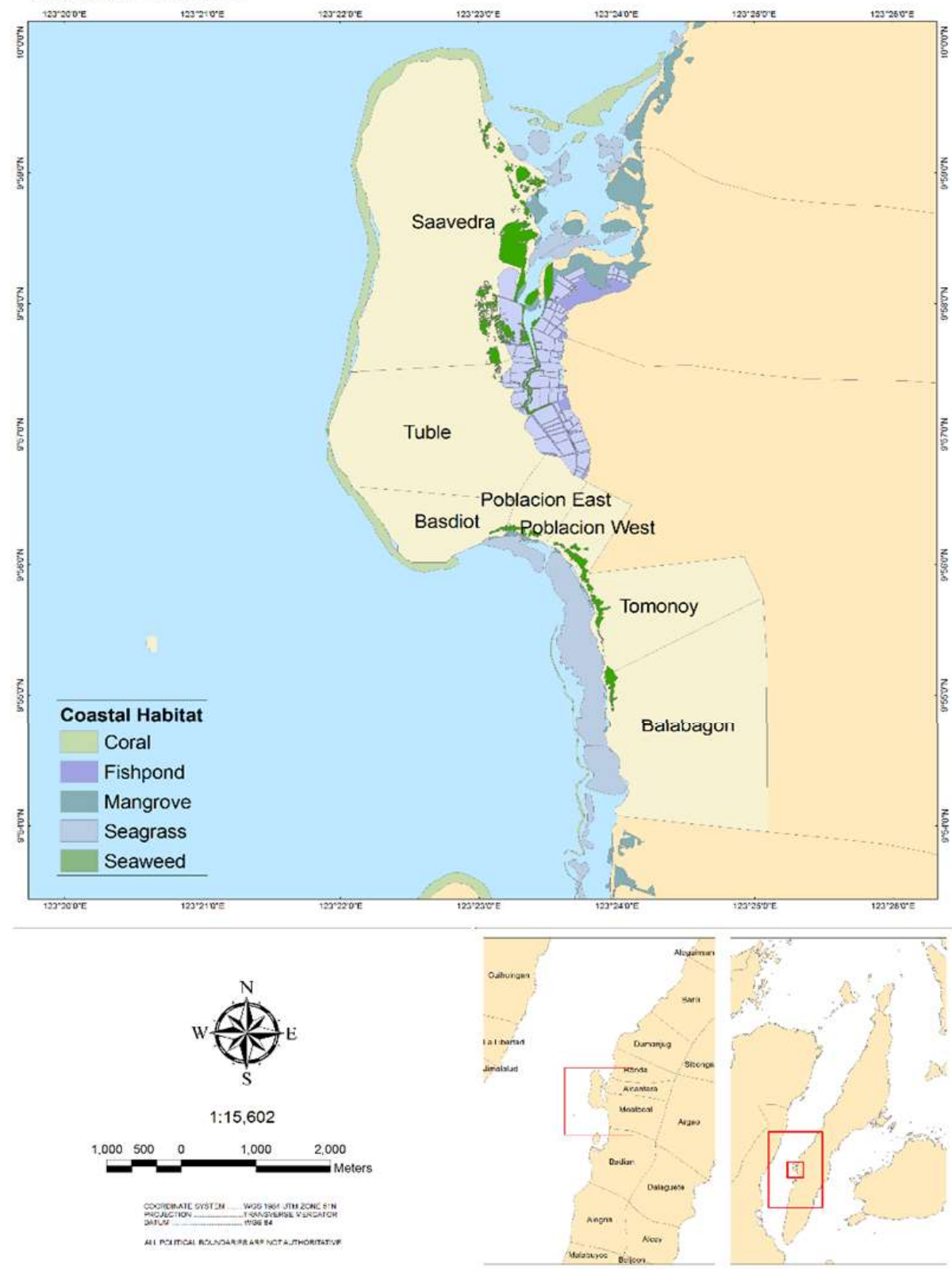

Figure 2. Location of survey site and coastal habitat 
Three major coastal habitats, ie, mangrove, seagrass and corals, in eight coastal barangays were surveyed and sampled. Prior to the seagrass and coral assessment, a manta tow was done at depth of approximately $5-8 \mathrm{~m}$ following the methodologies of English et al (1997) the percentage cover of benthic life forms was estimated. The results of these surveys were later used as basis for the site selections for detailed assessment of seagrasses and corals. In order to survey the mangrove areas, transect lines were laid from the seaward margin to the edge of the mangrove forest. In every $10 \mathrm{~m}$ of the transect line laid a $10 \times 10 \mathrm{~m}$ plot and three $1 \times 1 \mathrm{~m}$ subplots were established. In each plot, the species found were identified and the Diameter at Breast Height (DBH) measured. Mangrove saplings (girth less than $4 \mathrm{~cm}$ and height greater than $1 \mathrm{~m}$ ) and seedlings were also identified and counted. The girth was measured at breast height, approximately $1.3 \mathrm{~m}$ above the ground. For the seagrass, transect-quadrats $(0.5 \times 0.5 \mathrm{~m})$ was randomly established in the seagrass beds. The percentage cover of seagrasses in each quadrat was determined by recording the cover of each species.

A bathymetric survey was also conducted. A Trimble GNSS Base was set-up at the same point where the observation was done. The settings of the base were set to the desired settings for PPK (Post Process Kinematics) survey. The transducer unit of the Ohmex echosounder was then mounted to the poles and secured properly to the side of the boat. Trimble GNSS Rover and Trimble controller were also paired using Bluetooth and adjusted to the preferred settings. After the successful pairing of the rover and the controller, the main unit of the Ohmex echosounder was coupled to the Bluetooth logger and linked to the controller via software that was pre-installed on the controller. Once the set-up was fully operational, the bathymetric survey started by maneuvering the boat in a zigzag motion along the coastline. The boat was safely maneuvered to avoid damaging the coastal resources (seagrass and corals) in the area.

Focus group discussion (FGD) and key informant interviews (KII) were conducted in each coastal barangay hall in Moalboal. The activity was attended and participated in by at least 8 people from the municipal LGU, barangay officials, barangay tanod, Bantay Dagat (or "sea guardian" is a community-based law enforcement institution in the Philippines that engages fisherfolk in coastal villages or barangays on a volunteer basis to support the detection and enforcement of illegal fishing in coastal waters), and people's organization (PO) members. Specific topics were discussed from $30 \mathrm{~min}$ to $1 \mathrm{~h}$. All discussions were documented and recorded. The following topics were discussed: [1] community activities and existing organizations; [2] socio-economic information; [3] environmental threats and issues (eg, seasonal changes and waste management).

\section{Vulnerability Assessment Tool}

I-C-SEA Change and CIVATVA tools were built around a series of scoring rubrics to guide non-specialists in assigning scores to the three basic elements of vulnerability, namely exposure, sensitivity, and lack of adaptive capacity (MERF 2013). Found in the rubrics are lists of variables relating either to the present state of the coastal ecosystem (Sensitivity) or processes allowing the coastal ecosystem to cope with climate-associated impacts (Adaptive Capacity). Both rubrics have guidance of thresholds or standards identified for each variable. Thresholds 
correspond to numerical scores, which translate to Low, Medium, or High. Each variable was scored based on best available data for the given site.

Since both VA tools are participatory in nature, the researchers who conducted the rapid resource assessment requested experts and technical individuals to participate during the evaluation of variables in scoring the matrices and consolidating initial and subsequent data. The experts and technical individuals also assisted in data analysis and interpretation.

\section{Vulnerability Scoring}

In calculating the potential impact and then finally the vulnerability scores per coastal resource, a cross-tabulation approach was used (MERF 2013). Aggregate scores obtained respectively for the exposure, sensitivity and adaptive capacity components were subsequently rescaled into Low-Medium-High (L-M-H).

\section{GIS Integration and VA Scoring}

Different layers in GIS were generated based on LiDAR data and VA scores for each coastal resource (ie, mangrove, seagrass, and corals) (Figure 3). To compute for the potential impact and vulnerability, a tool was created in ArcGIS 10.2.2. Figure 4 shows the detailed framework for coastal vulnerability of seagrass. The same framework was used for mangroves and corals. All computations performed were submitted to the quality control (QC) team of University of the PhilippinesDiliman CoastMap before producing the final vulnerability maps.

The source of the exposure shapefile was from the study of David et al (2015). The hazard typologies from the study showed that the Philippines is naturally divided into 11 exposure clusters. These hazard typologies served as input to the VA tools used in this study. The VA framework (Figure 4) shows the map layer inputs (ie, GIS derived layers: raster and vector data), the geoprocessing (reclassification, intersect, join) used and the resulting output composite maps such as exposure, sensitivity, adaptive capacity and overall climate change vulnerability of the coastal resources of Moalboal.

\section{RESULTS AND DISCUSSION}

\section{Coastal Resources of Moalboal, Cebu}

\section{Mangroves}

Mangroves in Moalboal are classified as fringe or coastal mangroves. The Philippines has 35 true mangrove species (Long and Giri 2011, Primavera 2000). Ten (10) species of mangroves were identified during the rapid resource assessment namely: Avicennia alba, Avicennia marina, Avicennia rumphiana, Lumnitzera littorea, Nypa fruticans, Rhizopora apiculata, Rhizopora stylosa, Rhizopora mucronata, Sonneratia alba, and Sonneratia caseolaris. Barangay Saavedra has the most number of species (5), while Poblacion West has the least (2). Rhizopora apiculata and Sonneratia alba were the most common species among the six sites. Saplings and seedlings were also found throughout the study 


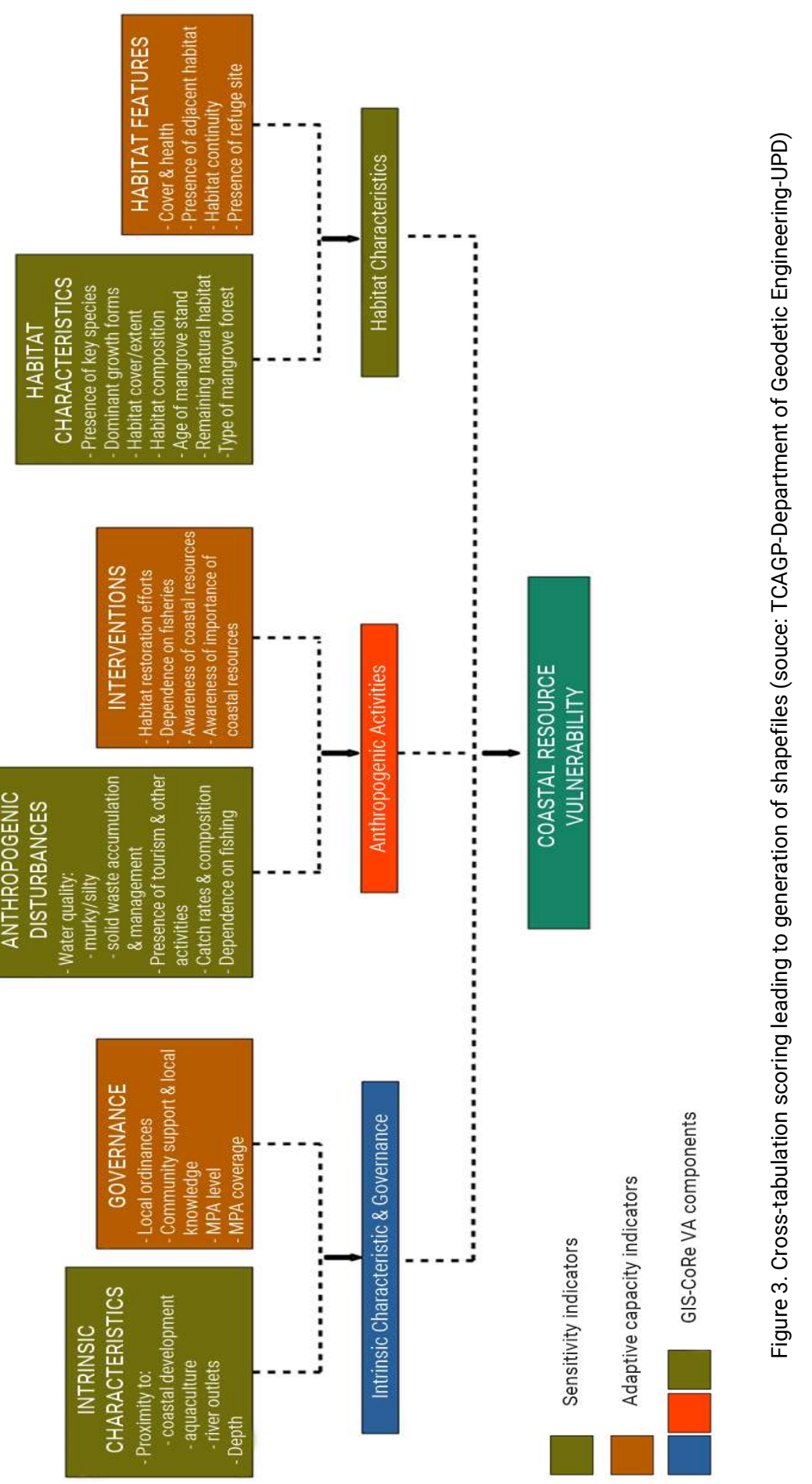


Diola et al
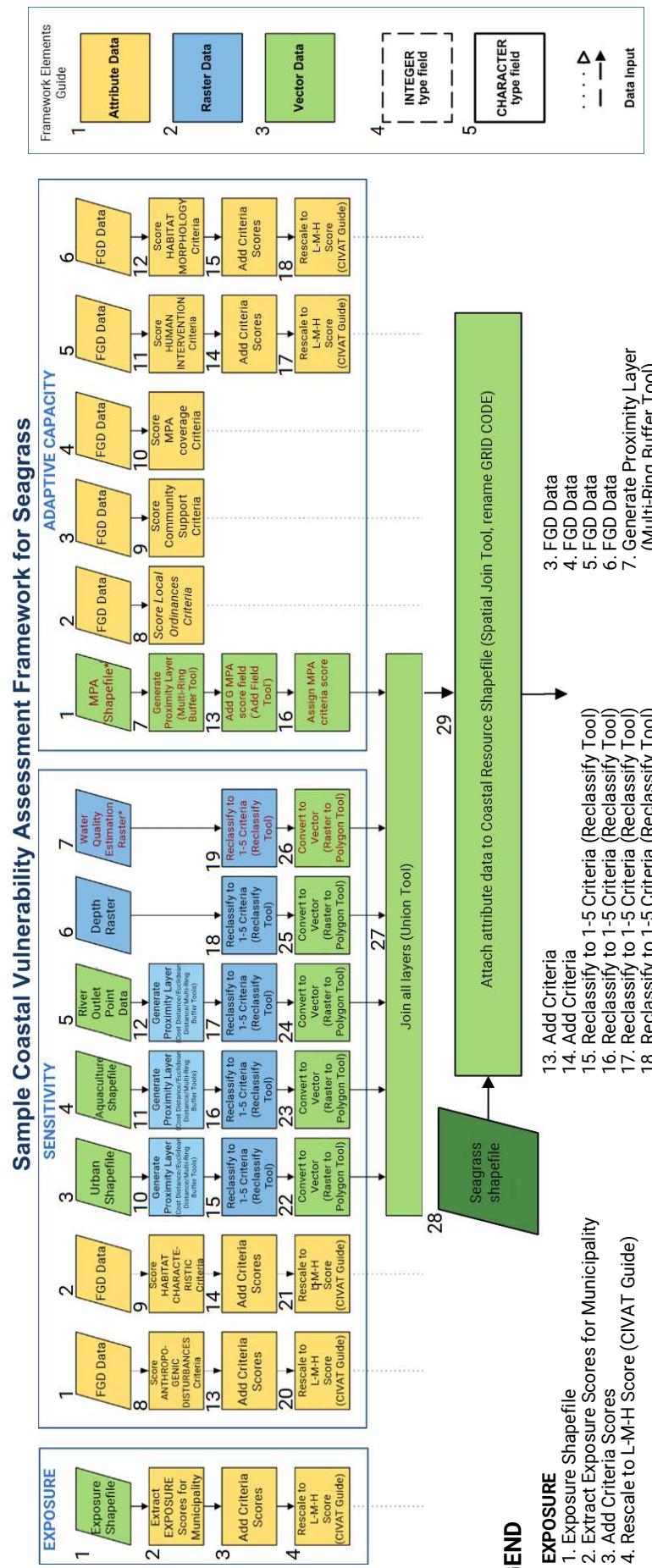

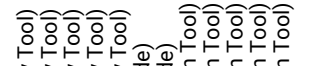

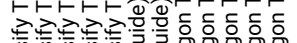

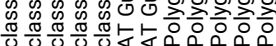

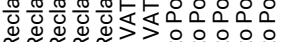

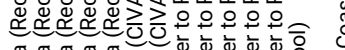

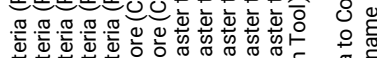

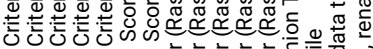

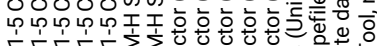

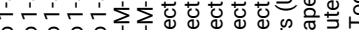

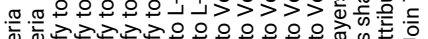

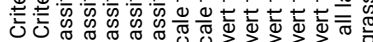

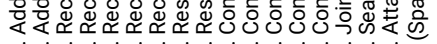

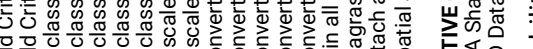

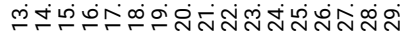

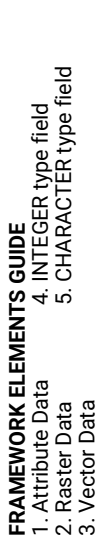

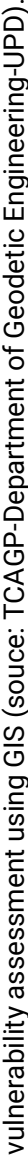
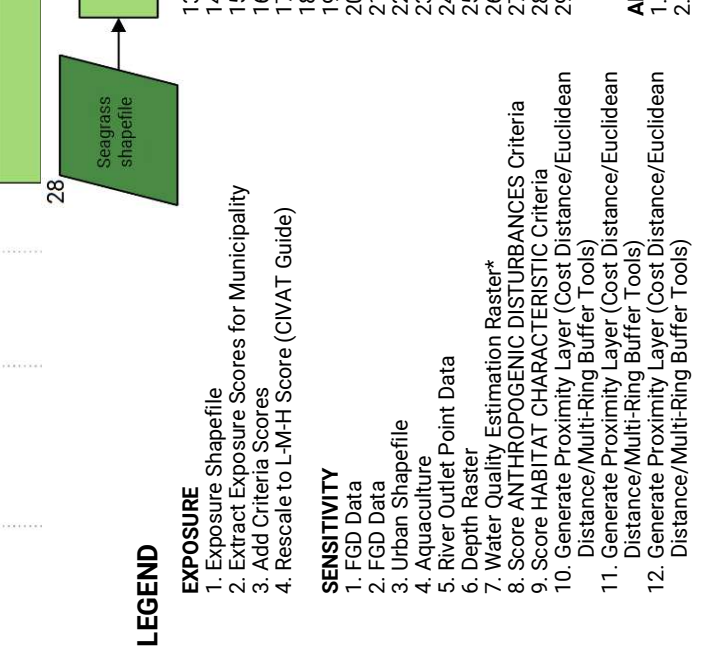


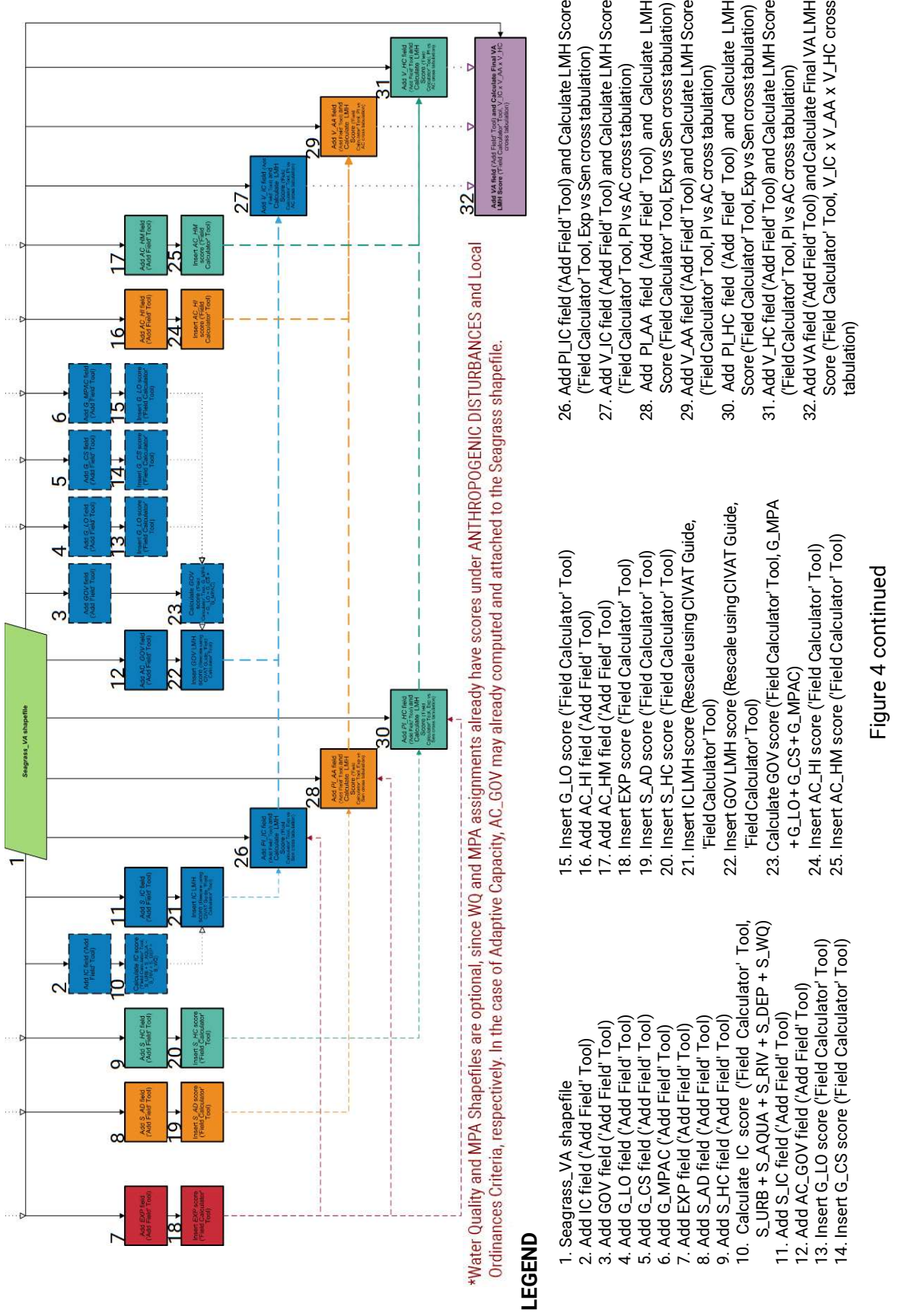


Mangrove mean DBH was highest at Poblacion West $(23.05 \mathrm{~m})$ and lowest at Saavedra $(7.21 \mathrm{~m})$. Mean mangrove height was highest at Poblacion West $(10.84 \mathrm{~m})$ and lowest at Balabagon $(2.49 \mathrm{~m})$. This suggests that Poblacion West has the least disturbed forest compared to the rest of the coastal barangays with mangroves. Also, it should be noted that Poblacion West is the only barangay implementing a no mangrove cutting/trimming policy. Mangrove cutting and trimming were seen mostly in the coastal barangays of Balabagon, Tomonoy, Poblacion East, Tuble, and Saavedra. From the results of the FGD and interviews, local inhabitants depend on the fishery and mangrove resources for their livelihood. Human activities directly affect the fringe forests, by eliminating plant cover and extraction of mangrove products, eventually resulting in poor mangrove forest quality. Mangroves have been used for centuries by people for wood, thatch, medicines, dyes, and as a source of fish and shellfish (FAO 2007).

\section{Seagrass}

Seagrasses are flowering plants and can be found in shallow coastal marine waters. There are 18 species of seagrass reported in the Philippines (Fortes 2013). Most of the seagrass beds were found within close proximity to mangroves and were formed in the shallow reef flat in Moalboal. Six species of seagrass were identified, namely, Cymodocea rotundata, Cymodocea serrulata, Enhalus acoroides, Halophila minor, Halodule pinifolia, and Syringodium isoetifolium. Estimated average seagrass cover for the following barangays were: $17 \%$ Basdiot, $22.5 \%$ Saavedra, 23\% Balabagan, 23\% Tomonoy, 23\% Poblacion West, and 23\% Poblacion East. Although the vegetation cover in the study area is sparse, seagrasses are important in many ways. They provide food and habitat for numerous marine species, maintain water quality, and help support local economies (serves as an important source of food and resources for livelihoods such as fishing and tourism for local communities) (Bertule et al 2017).

\section{Corals}

Estimated live hard coral for Moalboal was $54.26 \%$, soft coral $8.98 \%$, dead coral $3.89 \%$, dead coral with algae $13.89 \%$, and sand/silt/rubble $18.98 \%$. This estimated live hard coral cover is considered good (Gomez et al 1994). Live coral cover is a good measure of general reef health. Healthier reefs are generally characterized by relatively high coral cover. Reef-building corals are the main contributors to a reef's three-dimensional framework, the structure that provides critical habitat for many coastal organisms (Gattuso et al 2014).

\section{Exposure Maps of Coastal Resources}

Moalboal is under exposure Cluster $\mathrm{XI}$, in which sea level rise is the most likely disturbance that will have the greatest impact on the coastal zones (David et al 2015). Moalboal coastal resources (mangroves, seagrasses, and corals) exposure score is characterized as moderate. A very recent study published by Rietbroek et al (2016) showed that waters in the vicinity of the Philippines have above average sea level rise $(14.7 \pm 4.39 \mathrm{~mm}$ per $\mathrm{yr})$. How this estimate will affect individual islands in terms of area lost due to sea level rise is still unknown today due to the different 
geographic and topographic features which are inherently unique to each island. The studies by Church et al (2013) and Nicholls et al (2014) suggest that mean sea levels could rise by $1 \mathrm{~m}$ or more by 2100 , which will have severe impacts on coastal environments and ecosystems. Mangroves will be particularly vulnerable to sea level rise due to their strong dependence along the tidal profile (Albert et al 2017). Sea level rise can inundate and erode coastal habitats such as mangroves. Increase water depth causes the light availabilty on the seafloor to decease, which will lead to seagrass die-off in deeper water (Saunders et al 2013). At local scales, sea level rise is likely to increase sedimentation due to shoreline erosion which could smother reefs or reduce sunlight needed for photosynthesis. Ensuing effects from sea level rise on human coastal settlements on infrastructure and economies include inundation, flooding, coastal erosion, shoreline relocation or saltwater intrusion.

Integration and VA scoring for 3 aspects (Intrinsic Characteristics and Governance [ICG], Anthropogenic Activities [AA], Habitat Characteristics [HC])

\section{Mangrove}

The score of mangrove resources in Moalboal in terms of ICG was both high and moderate. High scores were found in most study sites except in some areas of barangays Tomonoy and Saavedra. Most of the human settlements in the barangay were in close proximity to mangroves habitats. Barangays with aquaculture activities were Balabagon, Poblacion West, Tuble, and Saavedra. In terms of AA, the potential impact was moderate however its vulnerability was low. This is illustrated by the growing coastal property development a few meters from the mangroves which may possibly contribute to the moderate score, while this is being countered by the continued habitat restoration efforts of the local government and the growing awareness by the communities of the importance of mangroves. Mangrove habitat characteristic $(\mathrm{HC})$ score was moderate. There are 10 species of mangroves in Moalboal representing $28.6 \%$ of the 35 total mangrove species in the Philippines. Many of these species come from a range of plant families and have growth forms from primary to secondary growths. The healthy stands appeared stable and longlived, but vulnerable from direct human pressures and removal, coupled with increasing threats from sea level rise.

\section{Seagrass}

Seagrass ICG score was from low, moderate to high. Potential impact was high in barangays Balabagon, Tomonoy, Poblacion West, and Saavedra. Although vulnerability scores were moderate in these barangays. This was due to the habitat's proximity to human settlements. Seagrasses are vulnerable to physical disturbances, such as wind-driven waves and storms. However, the direct and indirect effects of human activities account for most losses of seagrass beds (Fortes 2013). Both AA (Anthropogenic Activities) and HC (Habitat Characteristics) scored from moderate potential impact to low vulnerability. This could be attributed to siltation from agriculture, aquaculture, and land development that can also damage seagrass beds by both smothering the seagrass and blocking sunlight. The close proximity of seagrass and mangroves can greatly influence the physical, chemical and biological environments of coastal waters. They provide critical habitats for aquatic life, alter water flow and help mitigate the impact of nutrient and 
sediment pollution (Bertule et al 2017). The combined effects of human activities and the variety of climate-change related stressors will have a profound impact not only on the seagrass beds but also on other coastal habitats.

\section{Corals}

Corals' ICG and AA scores were mostly moderate in all study sites. Correspondingly, ICG and AA scores for vulnerability was mostly low. However, HC (Habitat Characteristics) scored high for potential impact and moderate for vulnerability. The moderate and low scores can be attributed to the fact that there are several marine protected areas (MPA) in Moalboal. Barangay Balabagon has a 3 ha marine sanctuary, Barangay Basdiot has two marine sanctuaries: a 5 ha in the mainland and a 4.5ha in Pescador Island, Tuble with a 5ha marine sanctuary, and Saavedra with an 8.13ha marine sanctuary (MPA Support Network 2014). These MPAs (Marine Protected Areas) were established between 1994 and 2007 and are managed by local POs. MEAT (Management Effectiveness Assessment Tool) score of these MPAs is Level 3, meaning the MPAs are effectively sustained (MPA Support Network 2014). These four MPAs are the main attractions for snorkelers and SCUBA divers from all over the world. However, the influx of tourists in relatively small MPAs can have a huge impact on corals. Tourists add to the pollution, waste, and water needs of the local population, putting local infrastructure and habitats under enormous pressure. A number of studies documented the impacts on coral reefs from divers and snorkelers (Meyer and Holland 2009, Leujak and Ormond 2007, Rodgers and Cox 2003, Rodgers et al 2003, Rouphael and Inglis 2001). The damage can be caused by fin kicks, pushing or holding the coral, dragging gear, and kneeling/standing on corals. These possible impacts have contributed to the high score on habitat characteristics (HC).

\section{Overall Vulnerability Maps of Coastal Resources}

Overall vulnerability to climate change of mangroves was moderate and low for both seagrasses and corals (Figures 5, 6 and 7). The high sensitivity, high exposure, and high adaptive capacity indicated moderate to low vulnerability. In other words, the present coastal resources in Moalboal are affected by the impacts of climate change. These coastal resources are therefore susceptible to the physical changes resulting from climate change (ie, sea level rise, extreme storm surges, flooding and enhanced erosion) (Nicholls 2011). Some of the potential impact was offset by the implementation and enforcement of local ordinances that were supported by the community through the establishment of MPAs, habitat restoration efforts, greater awareness of the community on the importance of a healthy coastal ecosystem, and the sustained management of these resources. Impacts on coastal systems are among the most costly and the most certain consequences of a warming climate (Nicholls et al 2007). Further changes in the current situation of the environment associated with human development activities can compromise the ability of these coastal resources to continue to provide a multitude of benefits including food, clean water, jobs, recreation, and protection from storms. For example, structural adaptations (eg, coastal erosion protection) do not necessarily discourage people from living in high-risk areas (eg, coastal erosion prone), but may encourage development and consequently, increase vulnerability. This emphasizes the fact 
that biophysical and human systems are not separate from each other, but should be treated as a dynamically interacting and co-evolving system that shares vulnerability (Klein and Nicholls 1999).

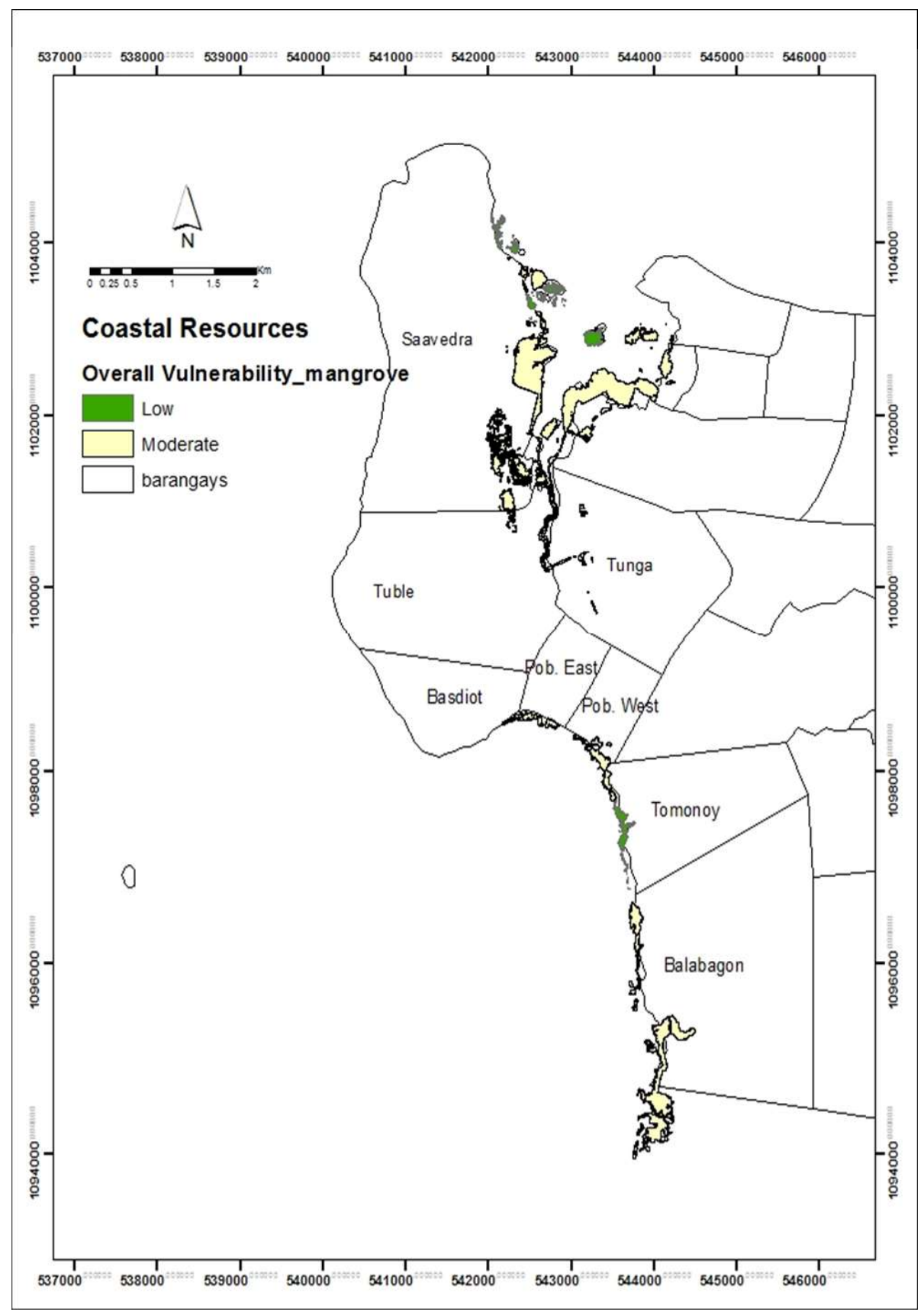

Figure 5. Overall vulnerability map of mangroves, Moalboal, Cebu 


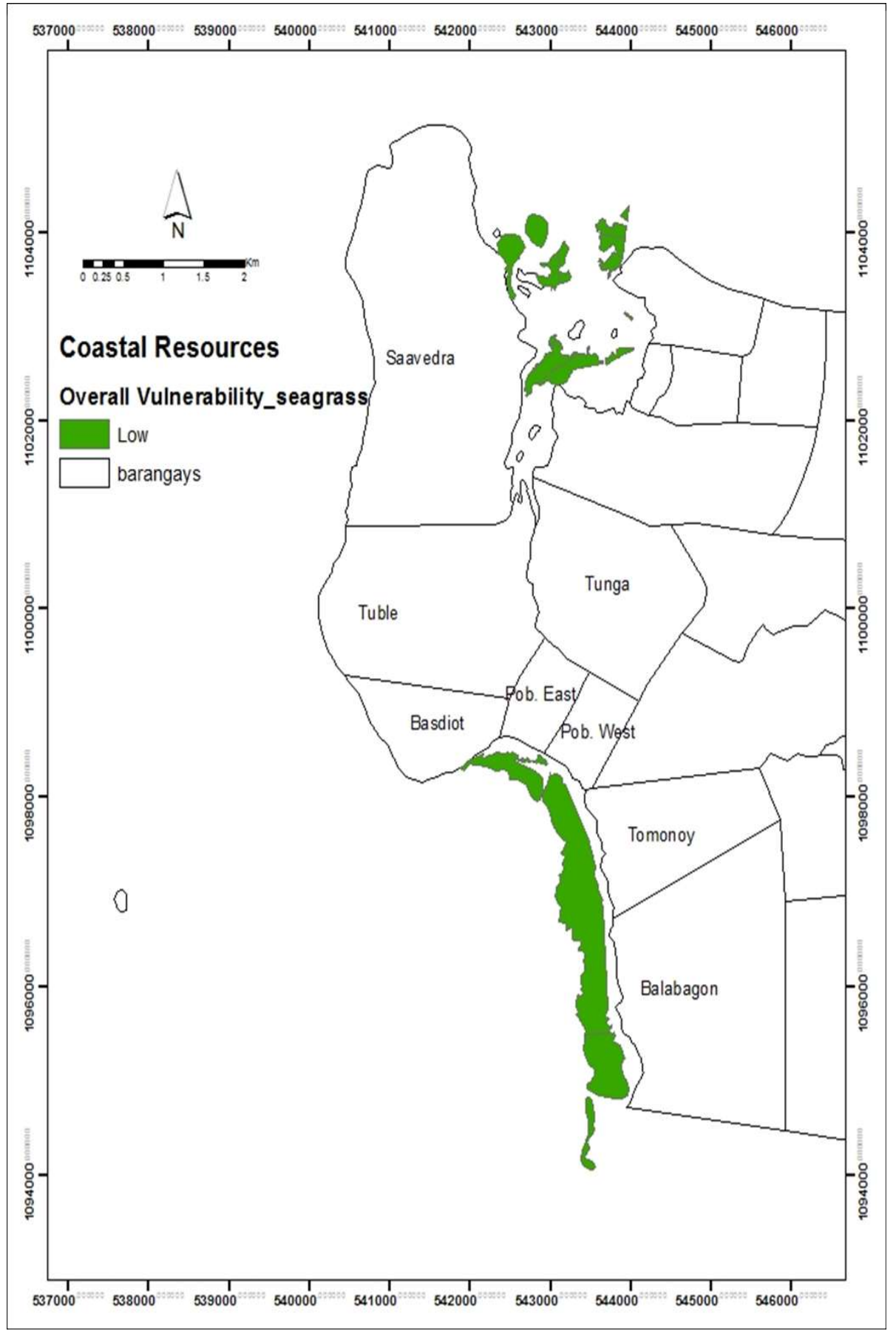

Figure 6. Overall vulnerability map of seagrass, Moalboal, Cebu 


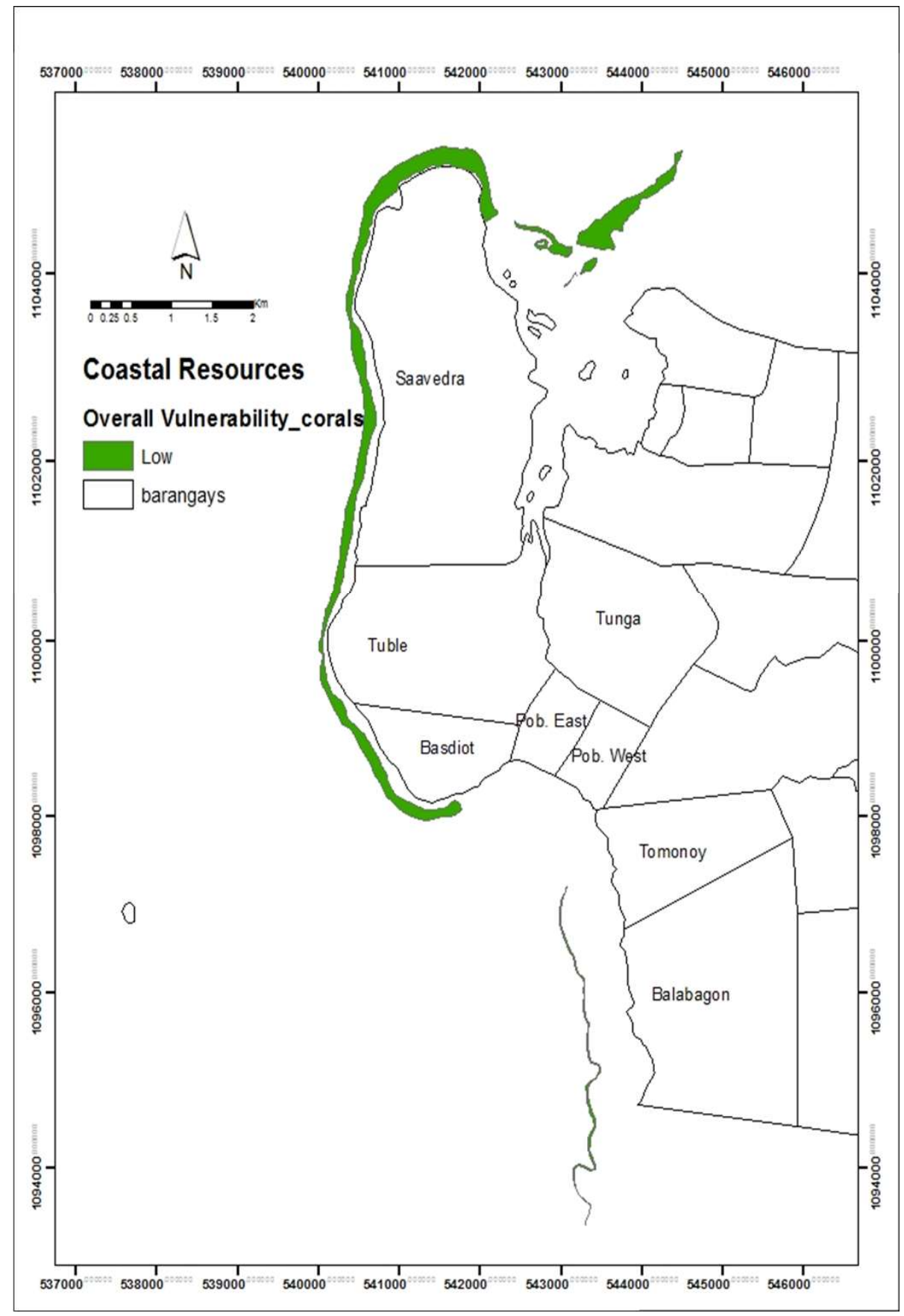

Figure 7. Overall vulnerability map of corals, Moalboal, Cebu 


\section{Adaption Options}

Adapting to the changing climate will be a challenge for Philippine coastal economies that contributed PHP1,411.1 billion (11.2\% of GDP) in 2014 (World Travel and Tourism Council 2015). These economies depend on coastal habitats, water resources, estuaries, and other natural resources to sustain them. However, climate change can also be used as a driving force for improving management. Integrated coastal zones management that is proactively participated in by GOs, NGOs, academe, and local communities should provide a major opportunity to address many issues and challenges of climate change. The work of Bijlsma (1997) and MERF (2013) provide options or a combination of options that can be incorporated into planning and management for coastal areas.

The results of this study can be used towards the design and development of adaptation strategies. Climate change adaptations can be directly integrated into existing decision-making frameworks regarding zoning of floodplains, coastal and emergency management, and disaster risk reduction.

The local government of Moalboal and its coastal communities will need strategies to enable them to manage current stressors and the confounding impacts of a changing climate to conserve, protect, and restore coastal habitats. Easing the existing pressures on coastal environments to improve their resiliency is one method of coping with the adverse effects of climate change. Coastal development is an indirect stressor leading to habitat loss. The major factors causing the degradation of coral reefs and other coastal habitats are increased siltation due to deforestation and agricultural practices, pollution, and overfishing. Policies must be created for the protection of not only the corals, but also the mangrove and seagrass habitats.

\section{CONCLUSION AND RECOMMENDATIONS}

There is a high concentration of population in the coastal area of Moalboal. Approximately 20 thousand people live in an area moderately vulnerable to sea level rise (or coastal flooding). Climate change can affect the coastal resources in Moalboal in a variety of ways. Growing population and development along the coastline of Moalboal can increase the vulnerability of coastal habitats, acerbated by climate change. In the last 30 years, the coast of Moalboal has provided significant benefits to the local economy, although the enforcement of rules and regulations represent major challenges for coastal management. Climate change and sea level rise aggravate the challenge of achieving sustainable development in coastal areas. Addressing these challenges may require new approaches to managing land, water, waste, and natural habitats. These require increased effort to move from a reactive to a more proactive response to coastal management. Strengthening integrated multidisciplinary and participatory approaches will also help improve the prospects for sustaining coastal resources and communities. The coastal community can take steps to mitigate the long-term risks from disasters, for example, by increasing their awareness about risks from hazards, protecting critically vulnerable coastal areas such as coral reefs, seagrasses and mangroves, protecting critical facilities such as barangay clinics/health centers and school buildings, and removing structures from hazard-prone areas. Local 
mitigation actions and concepts should be incorporated into land use plans and building codes to ensure that the plans and ordinances are mutually reinforcing. Local governments are responsible for protecting the health, safety, and welfare of their citizens. Proactive mitigation policies and actions should significantly help reduce risk and create safer, more disaster-resilient communities.

Due to variable interactions among sociopolitical and economic conditions, environmental systems and climate conditions, the vulnerability assessment cannot describe comprehensively the potential impact of climate change to the coastal resources. Based on our experience in this study, the integration of GIS in climate change vulnerability assessments contributed to efficiently identifying and mapping the current vulnerability of coastal resources to long-term climate change impacts. It also provided better visual presentations and understanding of the risk and vulnerabilities. Clear understanding of and accurate information on climate change risks are needed to support informed decisions on climate change adaptation. The stakeholders participation and provision of spatial and non spatial data for real-time and trend scenarios makes GIS an inclusive decision support system for vulnerability assessment. Moreover, the current vulnerability assessment can be improved by including sensitivity indicators such as climatic and geological history, biodiversity, demographics of the coastal populations; and adaptive capacity indicators such as social networks, social support, government and non-governmental institutions. Refinement in selecting and interpreting the most representative vulnerability indicators, as in this case, can reduce disaster vulnerability and risk, and foster disaster resilience.

\section{ACKNOWLEDGMENT}

We would like to thank the anonymous reviewers for their comments and suggestions. This paper is an output of "Project 8. LIDAR Data Processing and Validation by HEls for Detailed Resources Assessment in the Visayas: Central Visayas (Region 7) - CoastMap" under the research program Phil-LiDAR 2. Nationwide Detailed Resources Assessment Using LiDAR Program B. LiDAR Data Processing, Modelling, and Validation for Nationwide Resources Assessment headed by Dr. Ariel Blanco. We thank the Philippine Council for Industry, Energy and Emerging Technology Research and Development of the Department of Science and Technology (DOST-PCIEERD) for funding support. We acknowledge the research program Phil-LiDAR 1. Hazard Mapping of the Philippines Using LiDAR and DREAM, headed by Dr. Enrico Paringit, for the LIDAR data. The close collaboration between the USC Phil-LiDAR Research Center, University of San Carlos and the Training Center for Applied Geodesy and Photogrammetry, National Engineering Center, University of the Philippines-Diliman is hereby acknowledged. We also thank the University of San Carlos for moral, logistical, and financial support for the PhilLiDAR 1 and 2 research programs, and CCEF (Coastal Conservation and Education Foundation). Lastly, but certainly not the least, we thank our colleagues (Jay, Danilo, Arthur, Oliver) at the USC Phil-LiDAR Research Center for their assistance in data processing and field validation. 


\section{REFERENCES}

Albert S, Saunders MI, Roelfsema CM, Leon JX, Johnstone E, Mackenzie JR, HoeghGuldberg O, Grinham AR, Phinn SR, Duke NC, Mumby PJ, Kovacs E \& Woodroffe CD. 2017. Winners and losers as mangrove, coral and seagrass ecosystems respond to sea-level rise in Solomon Islands. Environmental Research Letters 12 (9):094009-1-094009-11

Bertule M, Appelquist LR, Spensley J, Trærup SL \& Naswa P. 2017. Climate change adaptation technologies for water: a practitioner's guide to adaptation technologies for increased water sector resilience

Bijlsma L. 1997. Climate change and the management of coastal resources. Climate Research 9(1/2):47-56

Bloemendaal N, Haigh ID, de Moel H, Muis S, Haarsma RJ \& Aerts JCJH. 2020. Generation of a global synthetic tropical cyclone hazard dataset using STORM. Scientific Data 7(1):40

Church JA, Clark PU, Cazenave A, Gregory JM, Jevrejeva S, Levermann A, Merrifield MA, Milne GA, Nerem RS, Nunn PD, Payne AJ, Pfeffer WT, Stammer D \& Unnikrishnan AS. 2013. Sea-level rise by 2100. Science 342(6165):1445

David LT, Rosario RBD, Peñaflor EL, Cordero-Bailey K, Villanoy CL, Aliño PM, Hilario F, de Guzman R \& Licuanan WR. 2015. Developing a Philippine climate-ocean typology as input to national vulnerability assessments. Proceedings from the $36^{\text {th }}$ Asian Conference on Remote Sensing 2015 (ACRS 2015): Fostering Resilient Growth in Asia, Crowne Plaza Manila Galleria, Quezon City, Metro Manila, Philippines, 24-28 October 2015

English S, Wilkinson C \& Baker V. 1997. Survey manual for tropical marine resources (2nd edn). Australian Institute of Marine Science, Townsville

Food and Agriculture Organization (FAO). 2007. The world's mangroves 1980-2005. FAO forestry paper 153. Food and Agricultural Organization, Rome, Italy

Fortes MD. 2013. A review: biodiversity, distribution and conservation of Philippine seagrasses. Philippine Journal of Science 142:95-111

Gomez ED, Aliño PM, Yap HT \& Licuanan WY. 1994. A review of the status of Philippine reefs. Marine Pollution Bulletin 29(1-3):62-68

Gattuso JP, Hoegh-Guldberg O \& Portner HO. 2014: Cross-chapter box on coral reefs. In Field CB, Barros VR, Dokken DJ, Mach KJ, Mastrandrea MD, Bilir TE, Chatterjee M, Ebi KL, Estrada YO, Genova RC, Girma B, Kissel ES, Levy AN, MacCracken S, Mastrandrea PR \& White LL (eds) Climate Change 2014: Impacts, Adaptation and Vulnerability. Part A: Global and Sectoral Aspects. Contribution of Working Group II to the Fifth Assessment Report of the Intergovernmental Panel on Climate Change (pp97-100). Cambridge University Press, Cambridge, United Kingdom and New York, NY, USA

Intergovernmental Panel on Climate Change (IPCC). 1996. In Houghton JT, Meira Filho LG, Callander BA, Harris N, Kattenberg A \& Maskell K (eds) Climate Change 1995: The Science of Climate Change. Contribution of Working Group I to the Second Assessment Report of the Intergovernmental Panel on Climate Change (pp572). Cambridge University Press, Cambridge, United Kingdom and New York, NY, USA

Klein RJT and Nicholls RJ. 1999. Assessment of coastal vulnerability to climate change. Ambio 28(2):182-187 
Leujak W and Ormond RFG. 2007. Visitor perceptions and the shifting social carrying capacity of South Sinai's coral reefs. Environmental Management 39(4):472-489

Long $\mathrm{J}$ and Giri C. 2011. Mapping the Philippines' mangrove forests using landsat imagery. Sensors 11(3):2972-2981

Marine Environment and Resource Foundation (MERF). 2013. Vulnerability assessment tools for coastal ecosystems: a guidebook. Marine Environment and Resources Foundation, Inc. Quezon City, Philippines

Meyer CG and Holland KN. 2009. Spatial dynamics and substrate impacts of recreational snorkelers and scuba divers in Hawaiian marine protected areas. Journal of Coastal Conservation 12(4):209-217

MPA Support Network. 2014. Philippine MPA Database. http://www.mpa.msi. upd.edu.ph

Nicholls RJ. 2011. Planning for the impacts of sea level rise. Oceanography 24(2):144157

Nicholls RJ, Wong PP, Burkett V, Codignotto J, Hay J, McLean R, Ragoonaden S \& Woodroffe C. 2007. Coastal Systems and Low-lying Areas. In Parry ML, Canziani OF, Palutikof JP, van der Linden PJ \& Hanson CE (eds) Climate Change 2007: Impacts, Adaptation and Vulnerability. Contribution of Working Group II to the Fourth Assessment Report of the Intergovernmental Panel on Climate Change (pp316-35). Cambridge University Press. London, UK

Nicholls RJ, Hanson SE, Lowe JA, Warrick RA, Lu X \& Long AJ. 2014. Sea-level scenarios for evaluating coastal impacts. Wiley Interdisciplinary Reviews: Climate Change 5:129-150

Philippine Statistics Authority (PSA). 2010. Population counts - Central Visayas. https://psa.gov.ph/sites/default/files/attachments/hsd/pressrelease/Centra l\%20Visayas.pdf

Perez RT. 2011. Assessment of vulnerability and adaptation to climate change in the Philippines coastal resources sector. https://pdfs.semanticscholar.org/4 d28/cdaac9140ad9afea345ce2b569f522fc2104.pdf

Primavera JH. 2000. Development and conservation of Philippine mangroves: institutional issues. Ecological Economics 35(1):91-106

Rietbroek R, Brunnabend S-E, Kusche J, Schroter J \& Dahle C. 2016. Revisiting the contemporary sea-level budger on global and regional scales. Proceedings of the National Academy of Sciences of the United States of America 113(6):15041509

Rodgers KS and Cox EF. 2003. The effects of trampling on Hawaiian corals along a gradient of human use. Biological Conservation 112(3):383-389

Rodgers K, Cox E \& Newtson C. 2003. Effects of mechanical fracturing and experimental trampling on Hawaiian corals. Environmental Management 31(3):377-384

Rosenzweig C, Casassa G, Karoly DJ, Imeson A, Liu C, Menzel A, Rawlins S, Root TL, Seguin B \& Tryjanowski P. 2007. Assessment of observed changes and responses in natural and managed systems. In Parry ML, Canziani OF, Palutikof JP, van der Linden PJ \& Hanson CE (eds) Climate Change 2007: Impacts, Adaptation and Vulnerability. Contribution of Working Group II to the Fourth Assessment Report of the Intergovernmental Panel on Climate Change (pp79131). Cambridge University Press, Cambridge, UK 
Rouphael AB and Inglis GJ. 2001. Take only photographs and leave only footprints? An experimental study of the impacts of underwater photographers on coral reef dive sites. Biological Conservation 100(3):281-287

Saunders MI, Leon J, Phinn SR, Callaghan DP, O'Brien KR, Roelfsema CM, Lovelock CE, Lyons MB \& Mumby PJ. 2013. Coastal retreat and improved water quality mitigate losses of seagrass from sea level rise. Global Change Biology 19(8):2569-2583

United Nations Environment Programme (UNEP). 2002. Global environment outlook 3. Earthscan, London

Yoo G, Hwang JH \& Choi C. 2011. Development and application of a methodologies for vulnerability assessment of climate change in coastal cities. Ocean and Coastal Management 54(7):524-534

Wong PP, Losada IJ, Gattuso J-P, Hinkel J, Khattabi A, Mclnnes KL, Saito Y \& Sallenger A. 2014. Coastal systems and low-lying areas. In Field CB, Barros VR, Dokken DJ, Mach KJ, Mastrandrea MD, Bilir TE, Chatterjee M, Ebi KL, Estrada YO, Genova RC, Girma B, Kissel ES, Levy AN, MacCracken S, Mastrandrea PR \& White LL (eds) Climate Change 2014: Impacts, Adaptation, and Vulnerability. Part A: Global and Sectoral Aspects. Contribution of Working Group II to the Fifth Assessment Report of the Intergovernmental Panel on Climate Change (pp361409). Cambridge University Press, Cambridge, United Kingdom and New York, NY, USA 